\title{
HISTORICAL SERIES (2001-2012) OF MICROBIOLOGICAL CONDITIONS OF THE CAPIVARI RIVER (RS), CONCERNING TO THE ESCHERICHIA COLI PARAMETER
}

\author{
Victor Rodrigues ARAGÃO ${ }^{1}$
}

${ }^{1}$ Universidade Federal de Santa Maria - UFSM. E-mail: aragaovr@ gmail.com

Recebido em: 25/04/2015 - Aprovado em: 21/08/2015 - Disponibilizado em: 30/10/2015

\begin{abstract}
The aim of this study was to analyze the microbiological quality in function of Escherichia coli of Capivari River, near the municipality of Capivari do Sul (RS), during the years of 2001 to 2012, apart from its influence on primary contact recreation. This study performed of documentary nature combined with quality quantitative properties, which provided the scope of the proposed objective. The results revealed that the parameter involved in this study was within the standard recommended by the CONAMA resolution 357/05, every year under study. There was no water resource degradation as a function of the parameter analyzed, being the years that showed major averages were 2003, 2007 and 2008, being lightly near the limit. These values can be explained by the region's rainfall, which led to the load of organic matter and animal feces to the riverbed, not being recorded releases of sewage and industrial effluents. In this way, the waters showed good microbiological quality in function of E. coli, with the absence of risk to the population as the primary contact recreation, being given to the promotion of activities foreseen for class 2 rivers, as animal watering, irrigation of vegetables and fruit.
\end{abstract}

Keywords: Microbiological quality, Documentary nature, Degradation, Rainfall, Rivers.

\section{SÉRIE HISTÓRICA (2001-2012) DAS CONDIÇÕES MICROBIOLÓGICAS DO RIO CAPIVARI (RS), EM RELAÇÃO AO PARÂMETRO ESCHERICHIA COLI}

\begin{abstract}
RESUMO: O objetivo deste trabalho foi analisar a qualidade microbiológica em função de Escherichia coli, das águas do rio Capivari, próximo do município de Capivari do Sul (RS), no decorrer dos anos de 2001 a 2012, além das suas influências na recreação de contato primário. A pesquisa se apresentou de cunho documental aliada a propriedades quali-quantitativas, o que proporcionou o alcance do objetivo proposto. Os resultados revelaram que o parâmetro envolvido no estudo esteve dentro do padrão recomendado pela Resolução CONAMA 357/05 em todos os anos em estudo. Não houve degradação do recurso hídrico em função do parâmetro analisado, sendo que os anos que apresentaram maiores médias foram 2003, 2007 e 2008, estando levianamente próximos do limite. Esses valores podem ser explicados pelas precipitações da região, o que acarretou no carregamento de matéria orgânica e fezes de animais para o leito do rio, não sendo constatados lançamentos de esgotos e efluentes industriais. Desta forma, as águas apresentaram boa qualidade microbiológica em função de E. coli, com ausência integral de risco para a população quanto à recreação de contato primário, sendo indicadas à promoção de atividades previstas para rios de classe 2 , como dessedentação de animais, irrigações de hortaliças e frutíferas.
\end{abstract}

Palavras-chave: Qualidade microbiológica, Cunho documental, Degradação, Precipitações, Rios. 


\section{INTRODUCTION}

While water can be a benefit to human health, can also be a means for raids, being directly or indirectly responsible for transmission of diseases, when contaminated, which are called from waterborne diseases. Although the water does not cause changes in health in relation to complaints, the balance of living things can be modified through the absence of certain minerals or lack of recommended dose. Soon, the water resources monitoring is essential, in addition to the time-even across dissimilar treatment types, when required (SAAE, 2014).

Nikaido et al. (2004) explains that the fecal-oral route is the most common form of contamination in living beings by microorganisms pathogenic enteric nature. The stools to be eliminated by an infected individual come into contact with food and water in direct and indirect form, leading to such contamination. According to Lepargneur (2004), about six thousand human deaths by complaints of severe nature are evidenced by day, more frequently in individuals during childhood, with oscillation between zero to five years of age.

To ratify the existence of agents related to pathogenicity in water, it takes into account the presence of bacteria of the coliform group, with genera of the family Enterobacteriaceae (PELCZAR JR et al., 1997; APHA, 1998).

According to Murray (2004), Escherichia coli is gram-negative bacillary bacteria which also concern the family Enterobacteriaceae, adstringe aerobic organism conditions and arbitrary anaerobiosis, having as natural habitat inside the human digestive tract of some animals pertaining to endothermy, more specifically in the intestinal lumen.

The presence of this microorganism in water or food is an indication of contamination from feces of human nature, or less frequently by other animals, being related to diseases such as urinary tract infection, appendicitis, cholecystitis, peritonitis, meningitis and septicaemia (PELCZAR JR et al., 1997; APHA, 1998).

There are an estimated through studies in epidemiology with the excreta, a human individual secretes an average of one trillion bacteria of this nature, in a period calculated in 24 hours. It is worth mentioning that the existence in vast quantities of these is common in intestinal of living beings, meanwhile, contamination of the individual is caused through the dissemination of these bacteria in other 
biotic parts of the body which perform functions essential to life; except in situations where the presence of inflammation in the lining of the intestines and the brain membranes and the spinal cord, termed enteritis and meningitis, respectively (PELCZAR JR et al., 1997; APHA, 1998; NIKAIDO et al., 2004).

The diagnosis in a human being with regard to the presence of disease through Escherichia coli is promoted from nature studies biochemistry, as well as on microscopic reflection of crops with the contaminated fluids. E. coli can promote the appearance of troublesome to sputum urine liquid endings, and burning sensations. There may also be the occurrence of five or more cells per field in the study of microscopic nature of urinary excreta.

According to Freitas et al. (1997), the microbiological monitoring of water resources contributes to the prevention of diseases relating to pathogenesis of fecal order, preservation of natural resources, in addition to note problematic individuals of economic slant, which promotes the use of water in a more conscious and sustainable. Thus, this study aimed to assess the microbiological quality of the Capivari river waters (RS), with emphasis in E. coli and its influences in relation to the primary contact recreation.

\section{METHODOLOGY}

According to the FEPAM (2014a), the Capivari River is located in the middle coast of the Brazilian state of Rio Grande do Sul, near the municipality of Capivari do Sul, with latitude coordinate (30S 07') and longitude (50W 29'), with an area of $161.24 \mathrm{mi}^{2}$ and $39.37 \mathrm{ft}$ of elevation relative to sea; the water body is located in the catchment area of the Middle Coast (L20), as shown in Figure 1.

Figure 1 - Location of the water body.

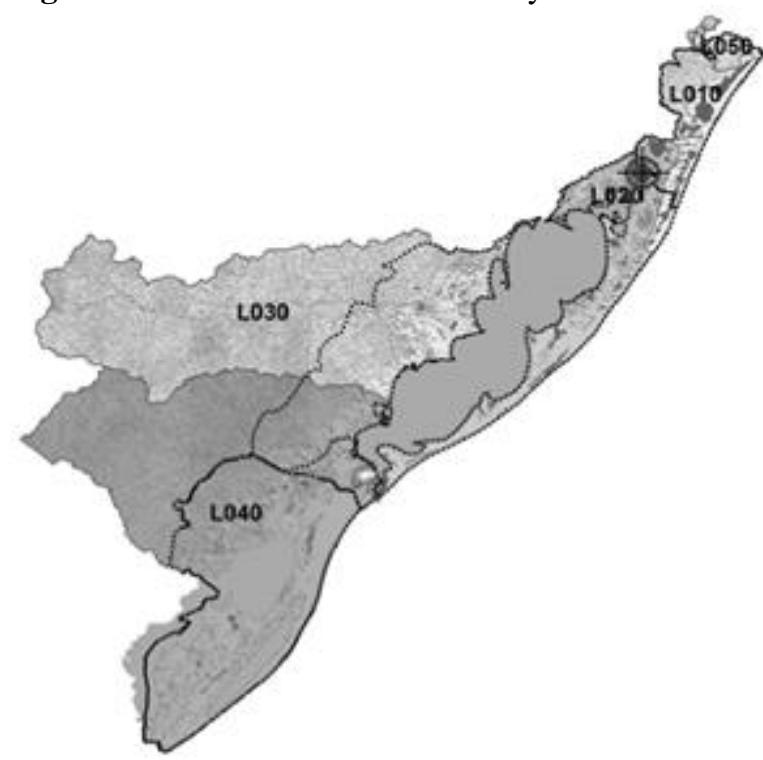

Source - Adapted from FEPAM (2014b).

The municipality involved in this study is at a distance of $39.06 \mathrm{mi}$ from Porto Alegre and receives identification number by FEPAM (2014a), designated by 4304671 ; is inserted in the metropolitan region of Porto Alegre and Osório's microregion, with neighboring municipalities: Palmares do Sul, 
South; Osório, Northeast; Balneário Pinhal, East; Viamão, West; Santo Antônio da Patrulha, North.

Officially published data were collected by FEPAM (2014a) of E. coli that comprised between the years of 2001 to 2012. Subsequently, this information was handled and arranged preferably in annual averages, with secondary discussions throughout the text in relation to the details of each month.

Multivariate analysis techniques have been inserted on data collection, in order to better characterize that water resource. The preservation and the analytical methods follow the procedures laid down by the Standard Methods (FEPAM, 2014a).

All the samples, from 2001 to 2012 were collected at 7.87 inches depth, approximately on the bridge in RS-040, where it makes the access to the river in the municipality of Capivari do Sul (RS).

The values for $E$. coli in rivers of class 2, according to CONAMA Resolution $357 / 05$, should not exceed a limit of 1,000 E. coli per $100 \mathrm{ml}$ in 80 percent or more of the samples analyzed; and the primary contact recreation is defined as the direct contact and for a relatively long period with waterbody (such as swimming, diving, water-skiing) where is present the possibility of water intake by the individual.
Thus, this study was based on a documentary research, which according to Gil (2002, p. 48), makes reference to the document analysis and interpretation of data from official precepts. In addition, together with preferential properties were the documental nature research, quantitative and quality methodologies provided to achieve the objective of this study. According to Santos (1999, p. 46), the qualitative researches are directed to the discovery, identification and thorough description. Quantitative already holds as defaults the statistical processes, mainly.

This research aimed to verify the quality of Capivari River in relation to their microbiological, more specifically with the presence of E. coli, taking into consideration the standards established by CONAMA resolution 357/05 of Brazil.

\section{RESULTS AND DISCUSSIONS}

In general, the results submitted for the E. coli did not compromise the primary contact recreation, especially in 2001, that was understood by the completion of two sampling campaigns, the first on March 11 with rate of E. coli in 110 MPN/100 ml and the second on August 27, which presented $387 \mathrm{MPN} / 100 \mathrm{ml}$; both the average of the two campaigns as samples on their individual shapes have been understood 
within the legal limit established by CONAMA resolution 357/05. Thus, there was no commitment from the aquatic system.

In 2002 were also cited two water sampling campaigns regarding the microbiological quality of the water resource in study, samples were included on March 22 , with presence of $345 \mathrm{MPN} / 100 \mathrm{ml}$, and in August 18, with 249 MPN/100 ml. It was observed that in relation to 2001 , there was an increase of E. coli in 2002 in sampling within the month of March, already in the month of August there was decreased. Through these results, we can conclude that in the second year there was an increase in average $E$. coli in $48 \mathrm{MPN} / 100 \mathrm{ml}$ (GRAPH 1), meanwhile, being within the standard indicated by the CONAMA resolution $357 / 05$.

After the initial two years, there has been an increase in large scale in two campaigns carried out in the year 2003. The same adduced an average of $581 \mathrm{MPN} / 100$ $\mathrm{ml}$, with sampling in March (same day as the March of the previous year sampling) and August (day 4). The level of E. coli in the first sampling of 2003 was close to the limit, which revealed 727 MPN/100 ml.
Graph 1 - E. coli annual averages (MPN/100ml).

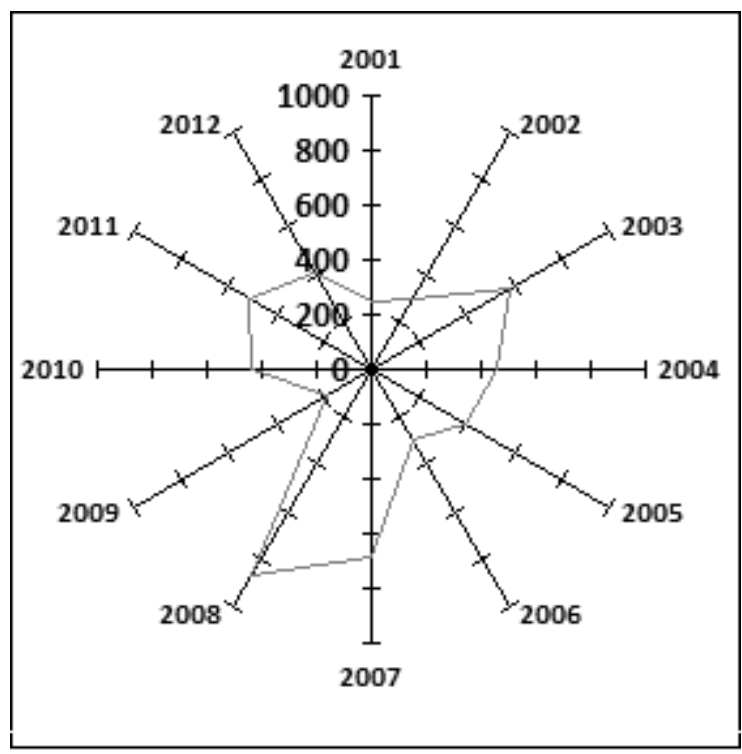

Source - Adapted from FEPAM (2014a).

The first year consists of only one campaign was that of 2004, where it presented the sampling in the month of July, the day 25, showing $461 \mathrm{MPN} / 100 \mathrm{ml}$. The year 2005 has an annual average difference of $71 \mathrm{MPN} / 100 \mathrm{ml}$ as compared to that of 2004. The fifth year of study was comprised of two campaigns, one on March 19 and the second on July 02. Both years described presented their first sampling tracks close to each other, with a difference of 26 MPN/100 ml. All campaigns of 2004 and 2005 were within the recommended standards, which promoted the hydric resource protection in all its different forms.

The first five years under study showed maximum variation of multiplication in the series 2002/2003 (1.95) and minimum of 0.79 in 2003/2004 series (GRAPH 2). A 
more broadly, Capivari River presented to 2001 to 2005 good quality as for Microbiology in function of E. coli, with all contents within the recommended pattern. Thus, there was no degradation in relation to this parameter in the hydric resource in the time period in question, a result unique to the waters near the municipality of Capivari do Sul, in monitoring station of FEPAM designated as CAP-0115. The results were not release fresh sewage over the River, and rural activities as cattle and pigs can be related with the contents found.

Graph 2 - Multiplication of growing year variable.

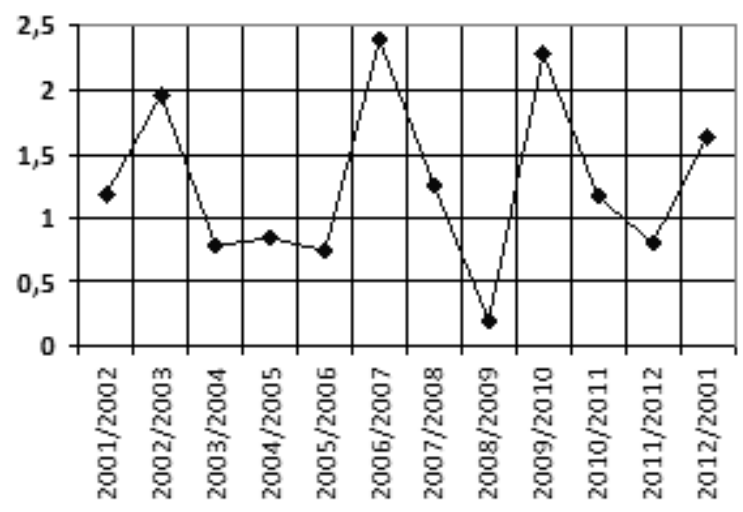

Source - The author.

The years of 2006, 2007 and 2008 were understood by each campaign, with spot checks on March 03, 2006, August 16, 2007, and also on August 16 in the year of 2008. The year that showed the highest rate of E. coli among the three years in question was that of 2008 , with 870 MPN/100 mL, being the year that revealed the biggest value of this microbiological parameter in all the years under study. The years 2007 and 2006 showed, respectively, 690 and 291 MPN/100 ml. Even with the high value in 2008, the same was within the standards required by CONAMA resolution $357 / 05$, as well as the years of 2007 and 2006. In this way, there was no proof of hydric resource degradation in any of its aspects congenital defects. In addition, it was observed fall of the multiplication of $2006 / 2007$ to $2007 / 2008$ of 1.88 .

In 2009 two campaigns were promoted, when the first one is in the March, in the day 26 , when there are presenting 180 MPN/100 ml, and the second sampling in the day 16 of July, in which it revealed 200 MPN/100 ml, with average of E. coli in 190 MPN/100 ml. In the next year there was only a campaign, being carried out in the March, in the day 11, in which there presented 435 MPN/100 $\mathrm{ml}$. With average of oscillation in $25 \mathrm{MPN} / 100 \mathrm{ml}$ regarding 2010, tenth year of the century XXI presented two campaigns (12 of January: 330 MPN/100 ml and 19 of July: 490 MPN/100ml. Besides, the year of 2011 also revealed two campaigns (17 of March: $250 \mathrm{MPN} / 100 \mathrm{ml}$ and 21 of July: 770 MPN/100 ml.

Can be observed through the Graph 3, that in ten of the twelve years there was absence of risk to the population rate in 
relation to the primary contact recreation, and the years of 2007 and 2008 showed, respectively, 0.5 and 1 percent, due to their means perform near the $900 \mathrm{MPN} / 100 \mathrm{ml}$. Even though these spreads have exited from scratch, can be disregarded, and affirm that there was complete absence of risk for individuals who attended the waters of water resource in the forms of primary contact recreation.

Graph 3 - Hazard rate for population in relation to the primary contact recreation.

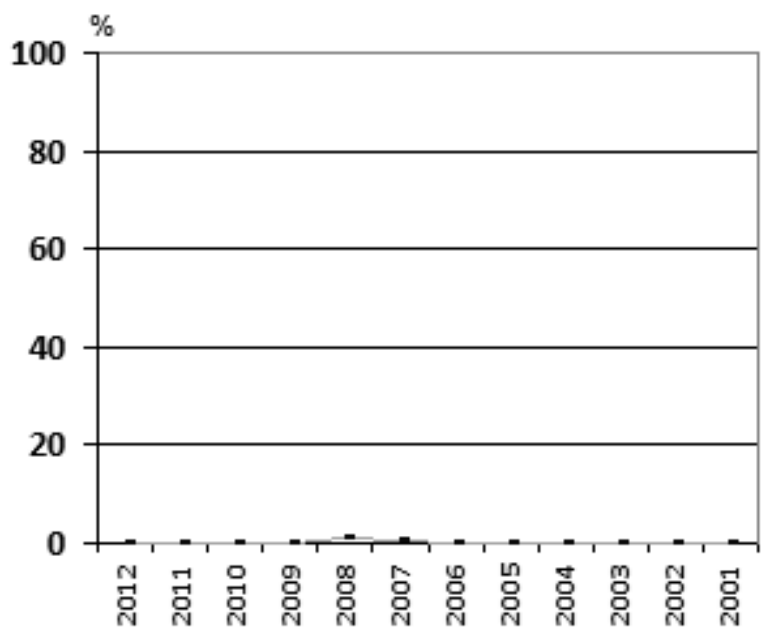

Source - The author.

Through parameter indexes emphasized in this study, there was the realization of good microbiological quality of Capivari River waters, near the municipality of Capivari do Sul (RS), in relation to the Escherichia coli.

Every year involved in this study were within the standard recommended by the CONAMA resolution 357/05. There was the protection of aquatic life in relation to the parsed parameter, as well as of nonrealization of the presence of domestic sewage and industrial effluents, being possible to conclude that variations, especially on a large scale from E. coli, were associated, mainly, with the precipitation of the State of Rio Grande do Sul, in which promoted the greater runoff and therefore the shipment of materials relating to animal feces and organic matter.

Thus, Capivari River waters can be used for the development of proposed activities for class 2 rivers by CONAMA, as animal watering, irrigation of vegetables and fruit trees and primary contact recreation.

\section{FINAL CONSIDERATIONS}

It was concluded through this research, Capivari River waters showed good microbiological quality in relation to E. coli, primarily in the years 2001, 2002, 2006 and 2009, and all the years under study were within the recommended pattern. The variations occurring of this parameter have been involved with the rainfall of the region, which led to the accumulation of coliforms, of animal origin in the water resource. In this way, its waters are free to be used in activities recommended for class 2 rivers, both related to bathing, as for irrigation and livestock supply. 


\section{REFERENCES}

APHA - American Public Health

Association. Standard methods for the

examination of water and wastewater.

Washington: American Public Health

Association, 1998.

CONAMA - Conselho Nacional de Meio Ambiente, 2005. Decreto 99274, de 6 de junho de 1990. Resolução 357, de 17 de março de 2005.

FEPAM - Fundação Estadual de Proteção Ambiental - RS. Qualidade Ambiental:

Região Hidrográfica das Bacias Litorâneas.

Disponível em:

<http://www.fepam.rs.gov.br/qualidade/moni tor_agua_litoral.asp>. Acesso em: $05 \mathrm{de}$ fev. 2014a.

FEPAM - Fundação Estadual de Proteção Ambiental - RS. Região Hidrográfica das Bacias Litorâneas. Disponível em: <http://www.fepam.rs.gov.br/qualidade/Imag ens/MapaImg/WEB_REG_LITORAL_GER AL.png>. Acesso em: 18 de mar. 2014b.

FREITAS, M. B. de; BRILHANTE, O. M.; ALMEIDA, L. M. de. Importância de Análise de Água para a saúde pública em duas regiões do estado do Rio de Janeiro:
Enfoque para coliformes fecais, nitrato e alumínio. Rio De Janeiro, 1997.

GIL, Antonio Carlos. Como elaborar projetos de pesquisa. $4^{\text {a }}$ edição. São Paulo: Atlas, 2002.

LEPARGNEUR, H. A água: qualidade de vida. $\mathrm{O}$ desafio do século. $\mathrm{O}$ mundo da Saúde, 28: 364-372. 2004.

MURRAY, P. R. Microbiologia Médica. $4^{\text {a }}$ edição. [S.1.]: Elsevier, 2004.

NIKAIDO, M.; OLIVEIRA A.S.; TREVILATO, T.M.B.; SEGURA-MUÑOZ S.I. Análise da qualidade da água do córrego Monte Alegre e afluentes, Ribeirão Preto, SP: enfoque para coliformes fecais e metais pesados. O mundo da Saúde, 28: 414-420. 2004.

PELCZAR JR. M.J.; CHAN, E.C.S.; KRIEG, N.R. Microbiologia: conceitos e aplicações. 2.ed. São Paulo: Pearson Education do Brasil, 1997.

SAAE - Serviço Autônomo de Água e Esgoto. Doenças de Veiculação Hídrica. Disponível em: <http://www.saaepirapora.com.br/saae/in dex.php/about-yjsg/2012-12-05-20-48- 
36/doencas-de-veiculacao-hidrica>. Acesso

em: 16 de março de 2014.

SANTOS, Antônio Raimundo dos.

Metodologia Científica: a construção do

conhecimento, Rio de Janeiro, DP \& A

editora, 1999. 